\title{
THE EFFECT OF USING WHATSAPP MESSENGER ON STUDENTS' SPEAKING ACHIEVEMENT AT THE SECOND GRADE STUDENTS OF MADRASAH ALIYAH NEGERI (MAN) 1 KENDARI
}

\author{
Aras Nur Ahmad T \\ English Language Education Department \\ Halu Oleo University \\ Email : arasnurahmad@gmail.com
}

\begin{abstract}
The use of technology in teaching and learning is an important aspect which has received considerable attention in recent years. In a similar sense, the use of mobile phone application especially WhatsApp messenger to increase effectiveness of instruction has been acknowledged through a number of studies carried out so far. This study was conducted to find the effect of using WhatsApp Messenger on students' speaking achievement at the second grade students of Madrasah Aliyah Negeri (MAN) 1 Kendari. The research question is that "Is there any significant effect of using WhatsApp messenger on students' speaking achievement at the second grade students of Madrasah Aliyah Negeri (MAN) 1 Kendari?" This study used a quantitative approach by applying a comparative study. The participants of the study consisted of 60 students who were in two different classes: class XI IPA 2 as the experimental class and class XI IPA 4 as the control class. The experimental class consisted of 30 students taught in a combination method (WhatsApp Messenger and discussion method) while the control class consisted of 30 students taught through using a conventional method. The results of this study showed that there were differences in the speaking achievement of the students in the experimental class and the control class. This difference was in favor of the experimental class. The value of Chi-Square count is 28.486 and the Chi-Square Table is 19.675. So the H1 accepted and H0 is rejected. The differences between the two classes indicated that integrating the WhatsApp application in teaching English language improved speaking achievement of the students of the experimental class.
\end{abstract}

Keywords: WhatsApp Messenger, Discussion, Speaking achievement. 


\section{Introduction}

The use of Information and Communication Technology (ICT) in teaching and learning process becomes a trend in today's education process. It is because the use of ICT is believed to bring benefits for both students and teachers. ICT can be used to support change and existing teaching practices. Educational practices of teachers using ICT can range from only small enhancements of teaching practices using what are essentially traditional methods, to more fundamental changes in their approach in teaching. ICT can be used to reinforce existing pedagogical practices as well as to change the way of teachers and students interact. However, many teachers are still unwilling to introduce the use of new technologies into the classroom. This is caused by some things that teachers are dislike to use ICT facilities, or teachers do not know how to use ICT facilities they have. In fact, if the teacher is able to apply ICT in the classroom, it will surely become a teaching practice and be able to become a new innovation in learning. Therefore, ICT is very important to support changes and to share existing teaching practices.

Students tend to learn only in face to face teaching process in the classroom, and less independent in learning. The discussion did not go well because students rarely ask questions in class. Students choose to be passive in class and are not engaged in learning. Some possible causes of passive students, including students do not understand the materials, students are embarrassed to ask in class, even are not interested in and do not bother with lessons given. As a result, when testing their material understanding, their values are less satisfactory. The situation becomes a challenge for teachers, especially teachers of English subjects. The learning process has been simply defined as the process of learning through face to face in the classroom. In fact, through a medium that allows learning without face-to-face, the learning process can still be taken place and the learning interaction between teachers and students can still be done.

In this study, The researcher will use WhatsApp messenger in teaching and learning process. It is a mobile application that employs users' existing internet data plan to help them networked and connected with others ( Ta'amneh., 2017: p.143). It is used for sending and receiving messages, video 
and audio messages. It has spread mostly among young people who are students and use it as an entertainment and a funny tool. They largely depend on it to know a lot of news around the world. Besides, the application may help them in their learning through exchanging information needed in learning the English language. Since it is used by most of students. It provides an access to learning resources when teachers and students are separated by time and distance. WhatsApp messenger as a method that can build up the students' motivation and support language skill such as speaking. The students learn by using WhatsApp messenger in the classroom of language learning and help them to increase their speaking skill which they can apply it both inside and outside of the classroom.

Based on the background stated above, this study attempts to answer the following question: "Is there any significant effect of using WhatsApp messenger on students' speaking achievement at the second grade students of Madrasah Aliyah Negeri (MAN) 1 Kendari ?". Thus, the objective of this research is to explore the effect of using WhatsApp messenger on students' speaking achievement at the second grade students of Madrasah Aliyah Negeri (MAN) 1 Kendari”. More specifically, it aims to compare between the students' achievements who are subjected only to conventional instruction (non WhatsApp messenger) in the classroom (control class) and those who used combination method (WhatsApp messenger and discussion methods) in their learning (experimental class).

As this study investigates the effect of using WhatsApp messenger on students' speaking achievement at the second grade students of Madrasah Aliyah Negeri (MAN) 1 Kendari, it is hoped that the results of the study will help educators and policymakers to understand the effect of new technological devices in the process of learning and teaching. Teachers may also be empowered by these results to look for ways of promoting their own professional development which may improve their teaching practices and their students' achievements particularly in speaking English. 


\section{Literature Review}

Salamat \& Pourgharib (2013) conducted a study to improve the speaking knowledge of EFL students on using mobile phones. 40 students including males and females up to 18 years old and with average age of 25 participated in this study. The participants in both experimental and control groups were provided with an opportunity to review and recycle English drills about speaking. In every session, the participants in the experimental group talk on their mobile phones in English. As an out of class assignment, they should practice their mistakes in English speaking. Participants in the control group, however, received no extra treatment at all. The results showed that the participants who had benefited from mobile-assisted learning had a significantly better performance on a speaking posttest than the participants in the control group.

Han and Keskin (2016) conducted a study to examine the effect of using WhatsApp activities in undergraduate level EFL speaking classes on students' speaking anxiety, and their feelings about the activities conducted. Thirty-nine undergraduate level participants carried out the tasks on WhatsApp in EFL speaking courses for four weeks. The FLCAS was administered at the beginning and end of the study. Participants' views about the mobile application activities were also examined through face-to-face interviews. The results showed that WhatsApp experiences significantly impacted the students' language acquisition by lowering EFL speaking anxiety.

Ta'amneh, (2017) conducted a study to find the effect of using "WhatsApp messenger" in learning English language among university students during the academic year 2015/2016. The participants of the study consisted of 40 first year university students. They were divided into two groups. The control group consisted of 21 students taught in a traditional way while the experimental group consisted of 19 students taught by using a combination between WhatsApp and traditional learning. The results of this study showed that there were differences in the achievements of the students in the experimental group and the control group. This difference was in favor of the experimental group. The differences between the two groups indicated that integrating the WhatsApp application in 
teaching English language improved the abilities of the learners of the experimental group.

Amry (2014) conducted a study to explore the impact of using WhatsApp mobile learning activities on the achievement and attitudes of online students using mobile devices at the university. The researcher selected 30 students to be in two groups (experimental and control). The e-learning process of the experimental group was depended on WhatsApp mobile learning activities whereas the e-learning process of the control group was only face-to-face learning in the classroom. A learning unit of the same course educational media was experimented with the experimental and control group. The t-test was used to compare the differences between the experimental and control groups. The results showed that there are differences, at 0.05 alpha level, in the achievements and attitudes of the experimental group compared with the control group in favor of experimental group.

\section{Methods}

This study used a quantitative research design by applying a comparative study. The design involved two classes as its subject (experimental and control classes) and it involved three steps: pre-test, treatments, and post-test. This design aimed to investigate the effect of using WhatsApp messenger on students' speaking achievement. There are two variables of this study. The independent variable is the method of teaching which has two levels; learning English through a combination method (WhatsApp and discussion method) and discussion method. The dependent variable is the students' speaking achievement.

The population of this study consisted of all the second grade students of MAN 1 Kendari, particularly, those who enrolled in a mathematical and natural sciences classes for the 2017-2018 academic year. The total numbers of student were 123. This study used a purposive sampling in selecting sample of the study. The samples of this study were two groups of third-grade students of MAN 1 Kendari who registered in academic year of 2017/2018. They were class XI IPA 2 as the experimental class and Class XI IPA 3 as the control class. The researcher chose the two classes based on the direction of English teacher. 
The instrument of this study was a test of English speaking ability that used as a pretest and a posttest. The researcher applied a test from an article for TEFL assessment adapted from Darmadi (2015: 3). The test was formed in two parts which were the pretest and the posttest. The test was in the form of interview by using a picture description technique. The samples took the pre-test to determine their actual level before starting the experiment, and the post test was given at the end of the experiment to evaluate the learners' achievement. The time interval between the pretest and the posttest was three weeks to minimize the effect of the pretest on the results of the experiment.

In this study, the researcher estimated the validity of the test by using SPSS 16 for windows as a tool inform Scale-reliability analysis to measure validity of the instrument. The items were valid if the value of corrected items total correlation is higher than $r_{\text {table }}\left(r_{\text {count }} \geq r_{\text {table }}\right)$. Based on the analysis, it shows that the Corrected Item-Total Correlation value of each item is higher than $r_{\text {table }}$ value. The result can be seen on the following table :

Table 1. Validity of the Instrument

$\begin{array}{ll}\text { ACCURACY1 } & =0.927>0.455 \\ \text { ACCURACY2 } & =0.942>0.455 \\ \text { FLUENCY1 } & =0.928>0.455 \\ \text { FLUENCY2 } & =0.936>0.455\end{array}$

Valid

Valid

Valid

Valid

The same case as measuring the validity of the instrument, the researcher also estimated the reliability of the test by using SPSS 16 for windows as a tool inform Scale-reliability analysis to measure reliability of the instrument. The instrument was reliable if the value of Cronbach's Alpha on SPSS data output is

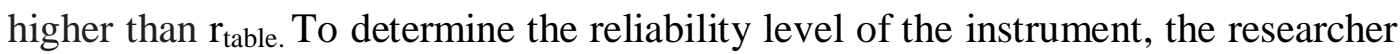
used Triton table reliability level. The result showed that the Cronbach's Alpha value was $0,946>0,80-1,00$, classified as very reliable.

To find out the result of this study, the researcher conducted a tryout to the pilot class that had been applied in class of XI IPA 3. The researcher did the tryout on $1^{\text {st }}$ February 2018 at $13.00-14.30$ AM in XI IPA 3 class. The researcher chose a 
different class because the researcher wanted to measure the validity and reliability of the instrument and wanted to measure the inter-rater agreement between two raters. After conducting the tryout to the pilot class, the researcher conducted a pretest to the students of XI IPA 2 class and students of XI IPA 4 class. The researcher did the pretest on $2^{\text {nd }}$ February 2018 at 10.10-11.30 AM in the experimental class and $3^{\text {th }}$ February 2018 at 08.0-9.30 AM in the control class. The researcher used a pretest because it had a benefit that was to determine the baseline score of each student. The pretest scores had been accumulated using the oral proficiency score category. In this study, treatment had been given in three meetings based on the topic of learning (procedure texts) of the lesson plan. In this study, the researcher only took 3 meetings. At the first meeting, the students taught about goal and materials. At the second meeting, the students had been taught about steps and at the third meeting, the students taught about imperative sentences, negative and positive. The researcher was applying a combination method (discussion method and WhatsApp Messenger) to the experimental class. While the control class applied the discussion method. The discussion method was done in the classroom. Another case of WhatsApp messenger users that had taken place outside the classroom. The use of WhatsApp messenger refers to discussion about task or assignment that had been done by the students. Tasks given by teachers will certainly be related to learning materials in the classroom (discussion method). After three meetings using a combination method (WhatsApp and discussion method) to the experimental class and advanced discussion method to the control class, the researcher gave a post-test to them. The researcher did the post-test on $2^{\text {nd }}$ March 2018 at 10.10-11.30 AM in the experimental class and $3^{\text {th }}$ March 2018 at 08.0-9.30 AM in the control class. The aim of giving the post-test was to find out the result whether there is a significant effect or not on students' speaking improvement in teaching English by using WhatsApp messenger.

\section{Findings and Discussion}

\section{Findings of the Study}

The purpose of this study is to compare between the students' achievements which are subjected only to the conventional instruction (non 
WhatsApp messenger) in the classroom (control class) and those who used the combination method (WhatsApp messenger and discussion method) in their learning (experimental class). The researcher applied the pretest and posttest for the two groups. Therefore, the data were analyzed through SPSS program to compute the means and standard deviations, as shown in Table 2.

Table 2 Comparison of Pre-Test and Post-Test Scores between the Experimental Class and the Control Class

\begin{tabular}{cccc}
\hline Method & & Pre-Test & Post-Test \\
\hline Experimental Group & Mean & 1.958 & 3.217 \\
$\begin{array}{c}\text { Combination Method } \\
\text { (Whatsapp And Discussion) }\end{array}$ & $\mathrm{N}$ & 30 & 30 \\
& Std. Deviation & 0.942 & 1.09 \\
& Minimum & 1 & 1.25 \\
& Maximum & 4.25 & 5 \\
\hline Control Group Conventional & Mean & 2.3 & 2.15 \\
Mathnd (nicmosinn) & $\mathrm{N}$ & 30 & 30 \\
& Std. Deviation & 0.881 & 0.995 \\
& Minimum & 1 & 1 \\
& Maximum & 4 & 4.5 \\
\hline
\end{tabular}

Based on the above table, it shows that the minimum score of the pretest of both class is 1.00 . The maximum score of the pretest of the experimental class is 4.25 while in the control class is 4.00 . The mean score of the experimental class is 1.9583 while in the control class is 1.7917 . And the standard deviation of the experimental class is 0.94249 while in the control class is 0.88103 . Besides, it shows the differences that very significant between the experimental and control classes in the posttest. It can be seen on the minimum score of the posttest of the experimental class is 1.25 while the minimum score of the posttest of the control class is 1.00. The maximum score of the posttest of the experimental class is 5.00 while in the control class is 4.50 . The mean score of the experimental class is 3.2167 while in the control class is 2.1500 . The standard deviation of the experimental class is 1.09019 while in the control class is 0.99481 . 


\section{Discussion}

Focused on the above results, it can be said that teaching speaking through combination method (WhatsApp and discussion method) helped students to improve their speaking ability especially on fluency and accuracy in conducting online discussions with their friends. This is certainly supported by several reasons: first, students get clear enough material explanations from teachers about learning materials inside and through WhatsApp starting from the topic of discussion, grammar and the structure of the procedure text. Second, teachers provide some directions to students about the systematic discussion, from the formation of discussion groups, discussion topics, and how to discuss, so they can know what they should do in the discussion. Third, teachers help students how to convey their ideas and opinions about procedure text to their friends in the form of spoken language by using the voicenote on WhatsApp messenger.

In the accuracy aspect, most of the students made many mistakes about grammar, in this case, the sentence structure that students used was still incorrect. when students were interviewed on the steps of making coffee, most of them sometimes explained with the structure of a random phrase. The example is when the teacher asked "this is the first step to make a cup of coffee, what it does ? then students answered "hot water" that should be "first, boil 2 glasses of water until boiling". The mistakes of students were made due to lack of students' knowledge about grammar in explaining procedure text such as temporal conjunction, action verb and complement. On the other hand, the lack of vocabulary became one of the factors causing the lack of ability of students in speaking.

In the fluency aspect, students still have many errors in pronunciation. this made them being unconfident to speak. For example: put a spoon of coffee into a cup. The word "put" that should be pronounced "put" but they pronounced "pat". Although, many students made mistakes in pronunciation, but they were still eager to learn the treatment process. After the treatment, most of the students developed their English speaking. They were also very active in discussing in and out of the class (WhatsApp messenger). The problem in the fluency aspect is 
actually due to the students' lack of confidence as well as the embarrassed and hesitant nature of speaking English. However, teachers certainly try hard to motivate students to be confident in speaking.

The result of the pretest and posttest shows that there was a significant improvement on students' speaking fluency and accuracy after being treated by using combination method (WhatsApp and discussion method). In the pretest, students' minimum score was 1.00 , the maximum score was 4.25 , and the mean score of the pretest was 1.9583. Meanwhile, the students' minimum score in the posttest was 1.25, the maximum score was 5.00, and the mean score was 3.2167. So, there is an improvement 1.2584 point of students' score from the pretest to the posttest after treatment. The result shows that the use of combination method (WhatsApp and discussion method) has a significant effect on students' speaking achievement.

\section{Conclusion and Recommendation}

\section{Conclusion}

The present study investigated the effect of using WhatsApp messenger on students' speaking achievement at the second grade students of Madrasah Aliyah Negeri (MAN) 1 Kendari". The findings indicated that the experimental group that used a combination method (WhatsApp and discussion) was better than the control group which taught using the traditional method (discussion). It can be concluded that English lessons can be learned more effectively through integrating technological applications such as WhatsApp messenger in learning English than the traditional methods.

\section{Recommendation}

The researcher addressed some recommendation based on the research findings that could be described as follows.

1. The English teachers are expected to be able to manage and implement combination method (whatsApp and discussion method) especially for improving speaking skill achievement. To build up the students' motivation, the teacher needs to group the students in the present study, it aims to avoid 
students' anxiety to speak in front of the class when the students speak individually.

2. The students are expected to be able to maintain what they have already had now. Therefore, the students must improve their English speaking skill by more frequently practice listening to the authentic English sources from the native speakers and practice to communicate in English with friends in the classroom or by using a mobile phone.

3. The institution of MAN 1 Kendari is suggested to improve the quality and more creative in teaching, especially in teaching English. In addition, the institution needs to give more motivation to the students to learn English in particular. It is aimed to make students more interested in learning.

4. It is hoped that other researchers would do better researches that related to the method that have been applied by the researcher. It was also expected that combination method (whatsApp and discussion method) could be applied in other skills of language, not only for speaking skill.

\section{References}

Amry, A. (2014). The Impact of Using WhatsApp Mobile Learning Activities on the Achievement and Attitudes of Online Students Using Mobile Devices at the University. European Scientific Journal August., 10, 22.

Darmadi, H. (2015). Assessing Procedure Text Through Simulation To The Tenth Grade Students of SMK Al-Madani Pontianak. An Article For Tefl Assessment.

Han., \& Keskin., (2016).Using a Mobile Application (WhatsApp) to Reduce EFL Speaking Anxiety. Gist Education and Learning Research Journal.

Pourgharib, \& .,Salamat. (2013). The Effect of Using Mobile on EFL Students Speaking. International Research Journal of Applied and Basic Sciences. 4 (11), 3526-3530.

Ta'amneh, M.A.A.A. (2017). The Effect of Using WhatsApp Messenger in Learning English Language among University Students. International Research in Education. 5 (1). 